\title{
A Splutter of Musketry? The British military response to the Anglo-Iranian oil dispute, 1951.
}

\begin{abstract}
This paper examines the British response to the crisis that resulted from the Iranian decision to nationalise the Anglo-Iranian Oil Company in 1951.The British government contemplated the use of military force from the outset of the crisis and a series of plans were developed. Unfortunately, in a manner similar to the Suez Crisis five years later, the military were unable to provide a suitable response until political considerations had made the use of force unattractive. Despite this, the Foreign Secretary, the Minister of Defence, and the Chiefs of Staff continued to press for an armed response. This paper uses newly released archival sources to examine the military plans and preparations and to analyse the way in which these interacted with political considerations to undermine the British position in Iran.
\end{abstract}

On 30 April 1951 the Iranian Majlis (parliament) passed a law nationalising the oil refinery on Abadan, an island on the Iranian side of the Shatt al Arab, the waterway that divides Iran and Iraq and flows into the Persian Gulf. The refinery and its facilities were the property of the Anglo-Iranian Oil Company (AIOC), a company in which the British Government was the majority shareholder. At this time the oil refinery at Abadan was the largest in the world and the Iranian oil field was the most productive in the Middle East. Abadan and the oil fields of southern Iran provided a major source of supply for Britain and AIOC profits and tax revenue provided the British Government with a valuable source of income and scarce foreign currency. The refinery at Abadan was seen as a national asset of strategic importance and its nationalisation by the Iranians caused outrage and consternation in Britain. In the crisis that followed the Attlee administration investigated the possible use of military force but in the end decided against this course of action, instead referring the case first to the International Court of Justice and later to the United Nations (UN), without success. As a result British AIOC employees withdrew from Abadan and the Iranian government took control of the refinery. The consequent loss of British prestige has 
been linked to later difficulties throughout the Middle East and ultimately to another nationalisation crisis, that of the Suez Canal in $1956 .^{1}$

In 1951 Britain possessed an army over 400,000 strong, had the second largest navy in the world and an air force more than capable of securing air superiority against the weak Iranian armed forces. Both the Foreign Secretary and the Minister of Defence were in favour of military intervention to secure Abadan. The leader of the Conservative Party, Winston Churchill, believed that all that was required to settle the matter was 'a splutter of musketry'. ${ }^{2}$ Against this background the non-use of military force during the Abadan crisis in 1951 is as interesting and instructive as was its use five years later against Egypt. The Abadan crisis was a key event in post-war British foreign policy. It is surprising therefore that, in comparison with the 1956 Suez crisis, it has received relatively little scholarly attention. ${ }^{3}$ The crisis revealed much about the state of the British armed forces in 1951 and the way in which military forces could both support and undermine political options. This paper will use newly released archive material to analyse the crisis from this angle, examining the various plans for military intervention and exploring the way in which military limitations influenced the political process.

\section{Genesis of the Crisis}

A detailed examination of the background to this crisis and of the political and diplomatic manoeuvrings that occurred is beyond the scope of this study. These issues have been addressed elsewhere. ${ }^{4}$ However, a basic introduction is required in order to understand the context in which military planning took place. British interest in Iranian oil dated back to 1901 when the first concession to drill for oil in Iran was 
granted. In 1908 major reserves were discovered in the south and by 1913 these were being carried by pipeline to a refinery on the island of Abadan. ${ }^{5}$ In 1933 the AngloIranian Oil Company, negotiated a sixty-year concession to extract oil and built-up the facilities at Abadan into the largest refinery in the world. By 1951 the AIOC had 70,000 Iranian and 4500 British employees. Working conditions for the former, while better than those of most Iranians, were in no way comparable to the far superior conditions enjoyed by their European counterparts. This was the cause of resentment in Iran and of moral discomfort amongst some Labour politicians.

In 1950 the AIOC made profits of $£ 170$ million, of which the British Government took thirty per cent in tax ${ }^{6}$ Under the 1933 concession the Iranian Government received royalties of between 15 and 20 percent. In 1950 the Iranian oil fields yielded 32.1 million tons of crude oil compared to 26.2 million tons in the US dominated Saudi Arabian fields. However, Saudi Arabia received an estimated \$112 million in direct payment from oil companies compared to only $\$ 44.9$ million for the Iranian government. ${ }^{7}$ Inevitably this inequitable situation caused resentment in Iran and brought pressure to renegotiate the 1933 agreement. The result was a Supplemental Oil Agreement in 1949, agreed between the Iranian government and the AIOC. Under this Supplemental Agreement royalties were to increase to a maximum of 30 percent. Unfortunately for the AIOC, before this agreement was ratified by the Majlis the Arabian-American Oil Company operating in Saudi Arabia concluded a deal based on a equal 50:50 split of profits between the company and the Saudi government. By early November 1950 the Iranians were aware of this deal and refused to contemplate anything other than an equivalent agreement. At the same time, a growing and very vocal body of opinion demanded nationalisation of what was seen as a key national 
asset. Neither the AIOC nor the UK government was willing to give way on either issue until it was too late. ${ }^{8}$

Strikes and riots were not uncommon at Abadan. In 1946 the British had deployed an Indian brigade and a Royal Navy cruiser to nearby Basra in Iraq when a general strike halted oil production and threatened the safety of AIOC staff. ${ }^{9}$ In the tense political atmosphere that existed in Iran at this time disturbances were inevitable. Political violence occurred across the country and in February 1951 the Prime Minister Ali Razmara was assassinated by religious extremists. Abadan was hit by a series of strikes amid agitation by nationalists and the communist Tudeh Party. Serious rioting on 12 April resulted in the death of three British subjects with six more injured. The following day the British Chiefs of Staff, the professional heads of the army, air force and navy, decided to send the Royal Navy cruiser HMS Gambia to the Gulf as a precautionary measure. Fortunately, Iranian troops were able to restore order in Abadan but the potential requirement for military intervention in order to protect British lives was to figure prominently in future British planning.

The dominant Iranian figure in this crisis was Dr Mohammed Mussaddiq ${ }^{10}$. Mussaddiq was the ageing but charismatic leader of the nationalist National Front. Characterised by many British observers (including both the Ambassador in Tehran and the Foreign Secretary in London) as a madman or a lunatic he proved to be neither. Mussaddiq became Prime Minister on 19 April 1951 on the basis of his nationalistic appeal and powerful performances in the Majlis. Within 12 days a Nationalisation Law had been passed by the Majlis and signed by the Shah and on 2 May the act of nationalisation passed into Iranian law. ${ }^{11}$ The Nationalisation Law 
cancelled the 1933 concession and nationalised AIOC oil assets. The British government referred the case to the International Court of Justice at the Hague on the basis that the Iranians had broken a treaty entered into freely and had refused to discuss or negotiate the dispute under the arbitration articles provided for in the 1933 agreement. In his memoirs Attlee claimed that it was not the act of nationalisation that he objected to but the fact that it had occurred without negotiation or appropriate compensation. Attlee also claimed that 'any attempt to coerce the Persian ${ }^{12}$ Government by the use of force was out of the question'. ${ }^{13}$ This was disingenuous. In reality the British considered the use of military force from the outset of the crisis and a series of plans were devised.

\section{The British Armed Forces}

In April 1951 the British Army was large by national standards. It had 202,000 regular troops supported by 223,500 National Servicemen and 7,500 women. ${ }^{14}$ Despite this, few troops could be made available for operations against Iran. With major commitments in Germany and Korea and involvement in the Malayan emergency and other imperial responsibilities the army was badly overstretched. The loss to Britain of the Indian Army with the independence of India and Pakistan in 1947 removed one of the key elements of British power beyond Europe. The resulting problem of overstretch caused the period of National Service (conscription) to be increased from 12 months to 18 months in 1949 and then to two years in $1950 .^{15}$ Unfortunately, the requirement to train National Service personnel tied down a significant proportion of the regular army. In 1950 the Imperial strategic reserve had consisted of the $29^{\text {th }}$ Infantry Brigade Group and the $16^{\text {th }}$ Independent Parachute Brigade. After the outbreak of war in Korea the $29^{\text {th }}$ Infantry Brigade was sent to the Far East and was thus unavailable for operations against Iran. 
The $16^{\text {th }}$ Independent Parachute Brigade was formed in 1948 after it had been decided to disband the $6^{\text {th }}$ Airborne Division. ${ }^{16}$ In 1947 an airborne division was formed by the reservist Territorial Army but the $16^{\text {th }}$ Independent Parachute Brigade was the only airborne force in the regular army and available at short notice. ${ }^{17}$ The Chiefs of Staff decided to deploy the brigade to Cyprus in May $1951 .{ }^{18}$ Initially the brigade was deployed to the Middle East in order to be ready to replace troops sent to Iran from Egypt. The Chiefs of Staff informed their subordinates in the Middle East that most of the brigade's troops were unfit for airborne operations, having received insufficient training. At most one or two companies could be employed, perhaps to seize Abadan airfield. ${ }^{19}$ Indeed, the transport aircraft accumulated by RAF Transport Command in readiness for any operation concentrated in the Suez Canal Zone and not with the airborne troops at Cyprus. Later military plans included the Parachute Brigade amongst the forces to be deployed to Abadan, however, this was in an infantry rather than a parachute role.

On paper the Royal Navy was an extremely powerful force. In 1951-52 it possessed five battleships, 14 aircraft carriers, 26 cruisers, 111 destroyers and 162 frigates. ${ }^{20}$ It was superior in size and strength to any other navy except that of the United States. Unfortunately, many of these ships were held in reserve or conducting trials and training, including all of the battleships and all but four of the aircraft carriers. Like the army, the Royal Navy had a range of commitments around the globe that it was struggling to meet. In particular, the deployment of a large maritime force to the west coast of Korea reduced the availability of both ships and trained manpower elsewhere. Nevertheless, the ability of the navy to control the sea in the Persian Gulf was not 
seriously open to question given the meagre assets available to Iran. The ability to exploit that control and to project power from the sea was more problematic.

Royal Navy cruisers and destroyers could bombard targets in Abadan, but the circumstances in which they might be called to do so appeared limited. Bombarding the oil refinery or its environs could do little in itself to achieve government aims. The most likely job for naval forces was to land troops either on Abadan island itself or on the south-west coast of Iran. Amphibious capabilities had been neglected since 1945. At the end of the war Britain had possessed an enormous amphibious fleet and had a knowledge and experience of amphibious operations rivalled only by the United States. Unfortunately a lack of priority saw the capability atrophy. By 1951 the only amphibious force that Britain possessed was the Amphibious Warfare Squadron based at Malta in the Mediterranean. This Squadron was designed to be able to lift an infantry battalion group and was capable of expanding to lift a full brigade group at 30 days notice. ${ }^{21}$ In reality it was frequently under-manned and below its supposed complement of active ships and craft. The ships that it did possess were old and obsolescent and ill-suited to the requirements of rapid military intervention. The only military unit that trained for amphibious operations, No. 3 Commando Brigade, Royal Marines, was fully occupied ashore in Malaya helping to fight communist insurgents. In any case, this unit had not received serious training in amphibious operations for some time. A small battalion sized unit, 41 (Independent) Commando, Royal Marines, had been raised in order to conduct raiding operations in Korea and had conducted numerous landings. However, employment in Korea meant that it was also unavailable for operations against Iran. ${ }^{22}$ 
The Royal Air Force (RAF) contribution to military operations in Iran was likely to fall into two basic categories. Firstly, and most importantly, it would be responsible for transporting troops by air into the theatre of operations. Secondly, it might also be required to provide fighter cover and close air support to troops on the ground. The government do not appear to have contemplated bombing 'strategic' targets in mainland Iran and there is no mention of such activity in the various plans discussed by the Chiefs of Staff. Equally, the Chiefs do not appear to have been too concerned by the problem of gaining air superiority over southern Iran. The Imperial Iranian Air Force was small and was equipped with obsolete aircraft of World War II vintage. ${ }^{23}$ The RAF had airfields at Bahrain and Sharjah both of which were British administered territories in the Persian Gulf and also at Habbaniya and Shaiba in Iraq. The latter were reinforced during the crisis. ${ }^{24}$

\section{Military Planning}

Even before the Nationalisation Law was passed the British Foreign Secretary, Herbert Morrison, had asked the Chiefs of Staff to examine the practical possibilities of taking military action in Abadan. In a letter dated 20 March he noted two potential constraints that would return to haunt British military planners in the months ahead. Firstly, he was concerned that nationalist pressure within Iraq might limit the potential of staging military forces there and that they might have to be held in readiness elsewhere in the Gulf, further away from Abadan. Secondly, Morrison was also concerned that military action might provide the Soviet Union with an excuse to intervene in Iran under the terms of the Russo-Persian Treaty of $1921 .^{25}$ The 
prolonged Soviet occupation of northern Azerbaijan at the end of the Second World War remained in people’s minds. ${ }^{26}$

In response to Morrison's request the Chiefs identified three alternative forms of military action:

1. A show of force without actually entering Iranian territory.

2. The provision of forces to protect British lives and property in the refinery area at Abadan and to evacuate British nationals.

3. The defence of both Abadan and the South West Iranian oilfields against action by the Iranian Government or mob violence.

A 'show of force' could be carried out by despatching a suitable naval force to the northern Gulf. Such an action could be done at relatively short notice. However, the Chiefs considered that the impact would be greater if an infantry battalion was moved to the vicinity of Abadan. Unfortunately the nearest British administered territories at Kuwait and Bahrain were some distance from the area in question and lacked the necessary facilities. Deployment to the RAF base at Shaiba (Iraq) would require the agreement of the Iraqi authorities. This might not be forthcoming. ${ }^{27}$

A plan already existed to cater for the protection of lives and property at Abadan. Code-named Accleton, this plan was based around the air-lift of an infantry brigade, minus one battalion, to Shaiba from whence they could rapidly move to Abadan should the situation demand it. ${ }^{28}$ The plan was designed to meet a local internal security problem and was based upon the assumption that Iranian forces would not 
oppose British intervention. It also assumed the availability of facilities in Iraq and could not be implemented satisfactorily without use of Shaiba. ${ }^{29}$ At their meeting on 27 March the Chiefs of Staff concluded that if these assumptions proved to be invalid then alternatives to Accleton would be required.

The Chiefs agreed that the protection of both Abadan and the oilfield area could not be afforded except at 'serious cost to our global strategy both in peace and war'. ${ }^{30}$ Even with the cooperation of Iranian forces an entire division would be required. Without such cooperation a larger force would be necessary. They noted that even if British military action should secure Abadan and the oilfields there was no guarantee that this would ensure the continued supply of oil as this depended on Iranian labour which was unlikely to be forthcoming in the circumstances. In addition to this, they advised, British military action might lead to difficulties in the UN, provide the Soviet Union with an opportunity to intervene in Iran and premature action could, by inflaming nationalist sentiment, actually endanger rather than protect British lives. ${ }^{31}$

At a meeting of the Cabinet Defence Committee on 2 April Morrison noted that it was too early to decide upon military action, except the move of certain naval units. It was therefore agreed that the Chiefs of Staff would keep plans in a state of readiness but that the premature move of troops might cause a hostile reaction in Iran and across the Middle East. ${ }^{32}$ After serious rioting on 12 April, and in the absence of more overt preparations, the cruiser HMS Gambia and two frigates were deployed to the northern Gulf. $^{33}$ 
On 3 May, one day after nationalisation was proclaimed as Iranian law, Attlee informed the Cabinet that he had decided to appoint a small group of ministers to 'watch the situation and to authorise action' that could not await consideration by the full cabinet. This 'Ministerial Committee on Persia' would comprise the Prime Minister (Attlee), the Foreign Secretary (Morrison), the Chancellor of the Exchequer (Hugh Gaitskell), the Minister of Fuel and Power (Philip Noel-Baker) and the Minister of Defence (Emanuel Shinwell). Within this group both the Foreign Secretary and the Minister of Defence were relatively hawkish. The Minister of Defence, Emanuel Shinwell, agreed with Morrison that military action might become necessary. On 1 May he had informed the Chiefs of Staff that '...the time might shortly come when it would be necessary to use strong arm tactics in Persia'. He believed that if the Iranians attempted to seize the oilfields without direct assistance from the Soviet Union then the UK should be ready to intervene with military force to protect the oilfields and associated areas. He was even willing to contemplate moving an army division from Germany to Iran for this purpose. ${ }^{34}$ The Chiefs were equally hawkish. On 9 May they informed the Ministerial Committee of their view that failure in Iran would undermine the whole British position in the Middle East and that they favoured taking a 'tough line' with Iran. However, they noted that the necessary military preparations might require partial mobilisation and the declaration of a state of emergency. ${ }^{35}$

On 5 May Morrison outlined to Attlee four alternative responses to the act of nationalisation. Firstly, Britain could freeze Iran’s Sterling balances, amounting to some $£ 25$ million, and cancel the Memorandum of Understanding under which Iran was provided with dollars in exchange for Sterling for certain purposes, including 
essential imports. Secondly, the AIOC could demand arbitration under Article 22 of the 1933 Concession Agreement. If the Iranian Government refused this then the British could present the case before the International Court of Justice at the Hague. Thirdly, the dispute could be taken to the UN Security Council. Finally, 'in the last resort', Britain could make a show of force. Morrison noted that there were serious drawbacks to each approach. At this point he would not recommend a show of military force as a means of resolving the dispute. Instead, he favoured sending an ambassador to Tehran to negotiate with the Iranian government.

In addition to Accleton the military developed Plan Bracket. Both plans were designed to protect British lives and property in Abadan and to secure the refinery and other AIOC installations on the basis of 'more or less' cooperative Iranian security forces. Accleton was based on the use of staging facilities in Iraq while Bracket catered for the more challenging situation where such facilities were not available. ${ }^{36}$ The Iranians were believed to have four infantry battalions on Abadan in addition to a naval and marine garrison of around 1200 men and around a dozen tanks and some armoured cars. The army reported that if there was organised military opposition then a larger UK force would be required and this was likely to mean that Britain would be unable to fulfil all of its NATO commitments and could even require a partial mobilisation of reserves. ${ }^{37}$

Accleton and Bracket were rapidly superseded by a new plan, Jagged, which also presupposed cooperation or at least non-intervention by Iranian forces. If this were not the case the forces allocated to Jagged could conduct Plan Midget, designed to cover the evacuation of AIOC personnel in the face of Iranian hostility. If Iranian 
opposition made the transfer of troops to Abadan by air impossible then the leading battalion would fly to Bahrain before transferring to a Royal Navy cruiser for sea transport to Abadan. The second contingent would fly to Abadan once the airfield had been secured. The Chiefs of Staff were happy that both Jagged and Midget were satisfactory plans and that they presented 'no particular military difficulty'. ${ }^{38}$

In the case of Midget this was a remarkably sanguine view. A single battalion packed into a cruiser would be capable of conducting an administrative landing at the port facilities at Abadan. However, although a cruiser could land small parties of troops in its own ships' boats it could not carry the large numbers of specialist landing craft that would enable its embarked force to conduct a landing against serious armed opposition. In view of the presence on Abadan of large numbers of Iranian troops, including tanks, it appears that Midget was only viable if the Iranians were willing to allow British troops to establish themselves ashore without a fight.

\section{Bold and Quick Action?}

Initially, elements within the UK armed forces appeared willing to countenance great risks in order to achieve swift and decisive action to secure Abadan. On 18 May the Chief of the Air Staff, Sir John Slessor, suggested that, given the likely poor quality of Iranian troops, the direct landing by air at Abadan of a brigade-sized force might be ' $a$ worthwhile risk' even in the face of armed opposition. This was particularly the case, he said, if fighter cover could be provided from airfields in Kuwait. ${ }^{39}$ The three service Commanders-in Chief (Cs-in-C) Middle East were thus instructed by the Ministry of Defence to submit plans for ‘bold and quick action' designed to seize 
Abadan island by fait accompli. In accordance with Slessor's suggestion, the first wave was to be of around brigade strength and would fly direct to Abadan airfield, covered by a fighter squadron operating from Kuwait (it was assumed that facilities in Iraq would not be available). The Cs-in-C were informed that the majority of the Parachute Brigade was not currently fit to carry out an airborne operation or to be employed in Iran. To make matters worse, the RAF transport forces in the Middle East were not operationally equipped or trained for the parachute role. ${ }^{40}$ However, there was a possibility of landing one or two companies by parachute to secure the airfield prior to the arrival of the main force. ${ }^{41}$

It is probably fortunate that the Chiefs of Staff eventually rejected such ideas. At their meeting on 21 May they agreed that a direct landing at Abadan airfield, as suggest by Slessor, was too risky. They considered that a 'proper operation, to include an opposed sea landing at Abadan' would probably be necessary. ${ }^{42}$ Field Marshal Slim, the Chief of the Imperial General Staff ${ }^{43}$, believed that the solution lay in landing as strong a force as early as possible. He favoured an amphibious assault, landing two brigades supported by a strong naval element and possibly accompanied by a two company parachute drop to secure the airfield. ${ }^{44}$ Unfortunately, this was not possible. Further investigation revealed that the armed forces were in no position to take immediate action. Neither the troops nor shipping to conduct such an operation was available in the Gulf. It was estimated that it would take six weeks from the time that orders were given before troops could be ashore in Abadan, by which time the Iranians were liable to have been reinforced. ${ }^{45}$ 
Both Slessor and Slim accepted that a quick operation was not viable. Slessor noted with some regret that 'Something of this sort had, however, been the only chance of action without our being faced with the need for full scale recapture operations'. In the light of these circumstances the Chiefs adopted a rather cautious tone, recommending the imposition of economic sanctions and the implementation of the Midget evacuation plan should the need arise. ${ }^{46}$ The Minister of Defence, on the other hand, remained hawkish. He declared, with remarkable prescience, that:

\footnotetext{
If Persia was allowed to get away with it, Egypt and other Middle East countries would be encouraged to think they could try things on: the next thing there might be an attempt to nationalise the Suez Canal. ${ }^{47}$
}

Unfortunately for Shinwell, Britain did not possess the necessary forces in the region to impose a swift and decisive military solution to the political problem.

\section{Plan Midget, Plan X and Plan Y.}

By 25 May the Chiefs of Staff had decided that in view of the strength of Iranian forces on Abadan Midget could not work as an airborne operation. Instead troops would have to be airlifted to the RAF base at Shaiba before conducting a land advance to the island. ${ }^{48}$ The Iraqi government reluctantly agreed that Shaiba could be used for this purpose, but only if the operation was limited to the protection of British lives. ${ }^{49}$ The idea of a land advance from Shaiba was later rejected in favour of moving troops from Shaiba to Abadan by ship or boat as an advance across 40 miles

of desert would 'not result in troops arriving in good condition'. ${ }^{50}$ However, by the 
end of June the planners in the Middle East were again pressing for the plan to be changed to cater for a land advance from Shaiba for forces landed by air and from Kuwait by those landed by sea. This was because the available ships and craft would have difficulties conducting an assault landing due to the prevailing tides, currents and beaches around Abadan. ${ }^{51}$ An additional problem was that no British troops in the Middle East were trained in amphibious operations. ${ }^{52}$ The land approach was politically vulnerable as it required unrestricted access through Iraq and this could not be guaranteed. ${ }^{53}$ It also appears to have neglected the fact that any military force advancing on Abadan by land would still have to cross the Shatt al Arab, presumably in the same ships and boats that would have been used in an amphibious landing.

Military plans were not limited to protecting British lives but also included a requirement to protect property and interests. Three plans existed:

1. Plan Midget: designed to cover the evacuation of British and other friendly nationals should there seem a prospect that their lives might be in danger.

2. Plan X: to seize and hold Abadan Island in the face of Iranian opposition.

3. Plan Y: to seize and hold both Abadan Island and the oilfields inland in order to ensure the resumption of oil production and export.

All three plans assumed the active opposition of Iranian forces which were described as 'not very formidable in quality'. Nevertheless, what they lacked in quality they made up for in numbers. There were now four infantry battalions, two marine battalions and a squadron of thirteen M4 Sherman tanks in Abadan with an additional infantry division 70 miles away in the Ahwaz region. ${ }^{54}$ 
Midget required the deployment of two infantry battalions and a force headquarters supported by air and maritime assets. The completion of certain preliminary moves, including the despatch of 15 Hastings transport aircraft to the Suez Canal Zone, meant that the plan could now be implemented at short notice. However, the Chiefs considered that the small number of forces employed meant that Iranian opposition would present a 'serious hazard' to its success. ${ }^{55}$

Midget had been sub-divided into three different operations, Courses A, B and C. Course A was based upon the airlift of two battalions of infantry direct into Abadan, the first troops arriving on D Day and the remainder flying in on D+1. The option was ruled out by Chiefs of Staff as too risky. Course B required the first battalion to fly to Shaiba and thence from Basra to Abadan by cruiser on D Day. The second battalion and supporting arms would either fly direct to Abadan on D+1 or follow the ShaibaBasra-Abadan route arriving on $\mathrm{D}+2$. Course $\mathrm{C}$ catered for the situation where Iraqi facilities were not available. The initial battalion would fly to Bahrain on D-Day and move by sea to Abadan on $\mathrm{D}+1$. The second battalion and supporting arms would fly direct to Abadan on $\mathrm{D}+1$ as soon as the airfield was secure. The timings in each case were dependent on 48 hours notice before D Day in order to concentrate and position ships, troops and transport aircraft. ${ }^{56}$

The military planners were concerned that activating Midget might have the opposite effect to that which was desired. There was a danger that the overt move of troops to Shaiba prior to their arrival at Abadan would provoke disturbances on the island that would pose a serious threat to British lives before arrival of the first troops. ${ }^{57}$ It was 
also noted that the requirement to meet the threat of a British landing might cause the Iranian security forces to neglect their obligation to protect foreign nationals. ${ }^{58}$ It was later agreed that a detachment of infantry should be maintained on a cruiser anchored close off Abadan. Poised offshore on the Iraqi side of the Shatt al Arab and available at a moments notice these troops could at least provide some form of military presence ashore prior to the arrival of the main force. ${ }^{59}$

The military were also concerned about the chances of success in Plan X. This plan could not lead in itself to the resumption of oil production as it would not ensure the supply of oil from the oilfields. Its main aim would be to 'induce a reasonable frame of mind in the Persian Government.' The Chiefs of Staff believed that for such a plan to succeed it would have to be capable of being carried out with limited forces, at very short notice and at great speed. Surviving records are incomplete, but Plan X appears to have been based on a plan codenamed Companion devised by the Cs-in-C Middle East at the request of the Ministry of Defence. The object of Companion was 'to move forces to seize and secure Abadan Island and to protect the refinery and other installations so that export of oil may be resumed as oil is received from the oilfields'. ${ }^{60}$ It was based upon the assumption that the very early arrival of a comparatively small force (two infantry brigades plus supporting arms) would enable the British to seize Abadan island and that surprise would effectively prevent successful resistance by Iranian forces. Ground forces were to fly direct to Abadan after the airfield had been captured by a small airborne operation by elements of the Parachute Brigade. ${ }^{61}$ As such it was an inherently risky operation. Given the build-up of Iranian troops in the area the Chiefs considered that the risk of failure was too great to make 
Companion/Plan X a sound military proposition without the level of forces allocated to Plan Y.

Plan Y was based on the seizure of both Abadan and the oilfields and a subsequent internal security operation to protect the refinery, oilfields and pipelines. It required a military force in the order of one infantry division, plus an additional infantry brigade, an armoured brigade and supporting units. It would also need appropriate support from air and sea. A military effort on this scale would have had serious implications for British commitments elsewhere. It would require the replacement of the entire Middle East garrison by forces from the UK. There would need to be a call-up of reservists and the partial mobilisation of the army. A large number of vehicles in the UK would need to be requisitioned. The transportation of the force would require 25 personnel ships and 35 freight ships and this would require further requisitioning. Once preliminary moves and redistributions had been completed it would still take between six and eight weeks for the leading wave of any force to reach Abadan and the full force could not concentrate there in less than four months.

The COS appeared well aware of political complications. They noted that even should UK forces succeed in seizing the oilfields and refinery intact, it was by no means certain that any Iranian personnel would be willing to work in them. The military appear to have been rather less hawkish than some of their political leaders. The Chiefs concluded that:

In the circumstances as they are to-day...there is in our view no certainty that this major military operation, involving a commitment of indefinite duration, would have any effect that might not equally well be achieved by political and 
economic measures - principally the withholding of tanker and marketing

facilities. $^{62}$

\section{Preparing for Action}

A key constraint for the military planners was the availability of shipping to transport troops and equipment. In late March the cruiser HMS Gambia had arrived in the Gulf and joined two frigates already stationed there. ${ }^{63}$ Conditions onboard the cruiser, at anchor and without air conditioning, were very difficult. On 5 May Gambia was relieved by HMS Mauritius which, in turn, was relieved by the cruiser HMS Euryalus in early July. ${ }^{64}$ The heavy guns of these cruisers made them very potent fire support platforms ${ }^{65}$ but they were not ideally suited to transporting large numbers of troops and equipment, nor were they equipped to land them in a tactical formation. For this purpose amphibious shipping would be required. Unfortunately, the provision of Landing Ship, Tanks (LSTs), the navy’s primary amphibious vessel, was a cause of concern. The Amphibious Warfare Squadron created in 1951 should have been capable of providing lift for a battalion group at short notice and a brigade group after thirty days. Unfortunately, the Squadron was based at Malta and it would take some time before any of its slow ships could complete the journey through the Suez Canal to the Gulf. A further problem was that many of the LSTs required for Plan Y had not had their decks stiffened and thus could not safely carry the army's new heavy Centurion tanks. ${ }^{66}$

Prior to the crisis the Royal Navy had no amphibious ships or craft in the Gulf. The LST HMS Messina sailed from Malta for the Gulf on 16 May, arriving off Bahrain 24 
days later. The ship then sailed to Basra. This ship was designed to embark around 15 tanks and 15 lorries or their equivalent and had accommodation for 150 troops. It could land the embarked force directly onto a suitable beach through bow doors. ${ }^{67}$ In addition to this the ship was also equipped with five small landing craft that could be lowered by davits and then sail independently to the shore. Each landing craft could carry around 30 troops. The ship was not designed to operate in the extreme temperature of the Gulf and was not equipped with air conditioning. Kept stationary at anchor yet required to maintain steam in order to be ready to sail immediately the ship became unbearably hot. Temperatures below decks reached over 50 degrees centigrade. Reportedly, all of the cockroaches on board died and all of the flies flew away. These beneficial side effects were mitigated by the fact that the ship’s cat, 'Snowy', had to be put down after becoming literally like 'a cat on hot bricks'. The scalding decks and bulwarks could also be a hazard to human health. ${ }^{68}$

The potential employment of HMS Messina was also rather hazardous. In the case of operations at Abadan it was to carry 150 tons of stores, ammunition, vehicles and equipment down the Shatt al Arab to Abadan. It would also embark infantry brought forward from the airfield at Shaiba. Unfortunately, the eastern bank of the river was Iranian territory and therefore the passage downstream could be opposed. In order to meet this eventuality, anti-tank guns were secured to the port side of the ship. These, in conjunction with the vessel's own anti-aircraft guns and the light machine guns and mortars of the embarked force, were designed to suppress any opposition. The shallow draft of the LST made it a useful vessel for riverine operations. Unfortunately, these ships did not carry any heavy armament nor did they have any armour. As such they were extremely vulnerable to enemy fire. It is remarkable that 
only two years after the Amethyst incident the Royal Navy was willing to consider sailing such a vulnerable vessel, packed with troops and equipment, in an opposed passage down river within sight and range of enemy forces.

It was not just the vulnerability of LSTs that was a cause of concern. Their availability was also a critical factor. In late June the Joint Planning Staff reported that although 16 LSTs were available in the UK and the Mediterranean it would take 30 days for the first one to reinforce Messina in the Gulf. To make matters worse only two more could arrive within less than two months. The majority of LSTs held in reserve or refitting in the UK could not reach the Gulf before September and some could not be made available before November. ${ }^{69}$

By the end of the month the Chiefs of Staff were able to report that if preliminary action was ordered by 2 July the leading elements of a UK force could reach Abadan by about 19 August. This was not a particularly rapid response. To make matters worse, such preliminary action could not be covert. The commissioning of the necessary amphibious ships would require the immobilisation of ten destroyers and frigates and two minesweepers. Men would have to be transferred from the Reserve Fleet and reservists would have to be recalled to service. The army would require an additional 10,000 men to bring the necessary forces to full strength and this would require the recall of reservists, the retention of regular troops due to leave and an extension of overseas tours. The government would also have to charter a number of civilian aircraft. $^{70}$ 
The need to overtly re-commission mothballed amphibious ships and to recall reservists meant that such preparatory moves could not be kept secret. The government was aware of the political implications of such action. Conscious of the difficulty of gaining and maintaining international support for military intervention, and constrained by the desire to wait for the results of an impending ruling by the International Court of Justice, the Cabinet decided that no preparatory action should be taken if it was likely to become known publicly. As the Cabinet minutes explained:

'...it would be unwise, in advance of this [court] decision, to take any steps which might suggest to the Court that the Government had it in mind to take the law into its own hands.'

Should the government decide to 'take the law into its own hands' very significant military forces would be employed. In order to seize Abadan island and to hold it for an indefinite period 17 personnel ships and 30 transport and stores ships would be required. These would be joined by 12 LSTs carrying 36 landing craft, a maintenance ship and a headquarters ship. The navy could provide two frigates or destroyers to accompany the amphibious force in addition to the cruiser and two frigates currently in the Gulf. The army would deploy the $1^{\text {st }}$ Infantry Division minus one infantry brigade, the $16^{\text {th }}$ Parachute Brigade and an armoured regiment, all of which were currently based in the Mediterranean or Middle East. If the operation was launched, these troops would have to be replaced by forces from elsewhere. The RAF contribution would include 24 Hastings long range transport aircraft, five medium range transport squadrons, two fighter/ground attack squadrons, a fighter/reconnaissance squadron and a light bomber squadron. ${ }^{71}$ This was a massive 
military force that would dwarf the British contribution to UN operations in Korea in every respect except that of surface warships.

In order to provide for a rapid response should Midget be implemented 15 Hastings aircraft were concentrated in the Suez Canal Zone. ${ }^{72}$ This, in addition to Valetta medium range transport aircraft allocated to the Middle East, was sufficient to lift a single battalion in the first wave. The Cs-in-C requested a further twelve Hastings so as to be able to lift two battalions simultaneously. ${ }^{73}$ On 2 July Ministers approved a Chiefs of Staff proposal for more airlift, including the use of chartered aircraft. Thirteen additional Hastings were sent to Egypt, arriving between 5 July and 7 July. In addition 10 civilian York airliners belonging to BOAC and the Lancashire Aircraft Corporation were chartered along with their crew. The aircraft were to carry RAF markings and the aircrew received temporary commissions. This removed restrictions that applied to civilian but not military flights into the Canal Zone. Due to congestion in Egypt the Yorks were based in Libya at Castel Benito, where they were near to their proposed passengers, the $1^{\text {st }}$ Guards Brigade. ${ }^{74}$ As a result it became possible to air lift three battalions forward on D-Day, two more on D+4 and a sixth unit by D+6. With the arrival in the Gulf at the end of July of War Department LSTs pre-loaded with heavy equipment, Midget could be implemented at short notice. ${ }^{75}$

On 25 June Slim had informed the Cabinet that it would take 36 hours to put Midget into effect. This could be reduced to 12 hours if the forces were assembled in advance. It could be reduced still further if they were flown forward to Iraq. The Cabinet approved the concentration of forces in Egypt (Canal Zone) but deferred a decision about moving troops to Iraq. ${ }^{76}$ This restriction did not apply to the pre- 
positioning of HMS Messina at Basra. ${ }^{77}$ Ministers later agreed to the limited prepositioning of troops and stores at Shaiba but only on the basis that these were kept to the absolute minimum required for advance parties and the maintenance of stores and that they must in no circumstances include formed units. $^{78}$

The problem facing the British was that in order to protect British lives it was important to get sufficient troops ashore at the first opportunity. Troops held offshore in the cruiser could land at very short notice and could be supported by the ships guns once ashore. However, there would not be enough of them to guarantee the safety of British nationals. Pre-positioning ground and air forces at Shaiba could ensure a rapid response but had potential drawbacks. Shaiba was an unpleasant place to stay in the heat of the Arabian summer and it lacked facilities for the brigade-sized force now envisaged for Midget. The premature deployment of a military force to Iraq could not be hidden and might cause unrest amongst local Iraqi nationalists and Iranian nationalists in Abadan. Midget (and later Buccaneer) relied on a degree of surprise for success. Deployment of troops to Shaiba would remove any element of surprise and could prompt the Iranians to move their division from Ahwaz to Abadan, or possibly even to take AIOC personnel as hostages. As a result, Cs-in-C were informed that they could pre-position Midget forces at Shaiba on or after 25 July but only 'if the situation in the oilfields has become so critical as to make it probable that “BUCCANEER" will be ordered in the immediate future.$^{79}$ In the event, no infantry battalions deployed to Iraq although the RAF did deploy fighter/ground attack aircraft at Shaiba and Habbaniya. 
It is noteworthy that throughout the crisis the Royal Navy did not deploy an aircraft carrier to the northern Gulf. In 1951-2 the Navy had 15 carriers, of which four were on active service. ${ }^{80}$ On 30 May 1951 the Chiefs of Staff requested the Admiralty to investigate the possibility of providing such a ship. ${ }^{81}$ An aircraft carrier would have been particularly useful as it could have provided fighter and strike aircraft to cover operations in Abadan if facilities in Shaiba were not available. The only viable alternative to Shaiba, Kuwait, was at the extreme limits of range for RAF jet fighters and as the airfield facilities at Kuwait were very basic the military planners were forced to conclude that the air support plan for operations larger than Midget could not work without use of Shaiba. ${ }^{82}$ This was rather unfortunate as the Iraqis would only allow use of Shaiba for operations designed to protect British lives, i.e. Midget but not Plan Y. An aircraft carrier would have alleviated these difficulties. However, with the requirement to maintain a carrier in support of UN operations in Korea and residual commitments around the globe the Admiralty clearly felt that the could not provide one of these vessels on call to support potential operations in Iran.

\section{Political Complications}

These military difficulties were exacerbated by political factors. A clear problem for the British was the attitude of the United States towards the use of military force at Abadan. The American position was communicated to the British government in unequivocal terms. The US Secretary of State, Dean Acheson, and President Truman both expressed great concern that the British might use military force against the

existing Iranian administration. ${ }^{83}$ The Americans were clearly opposed to military action to seize Abadan and were less than enthusiastic about an armed response 
designed to protect British lives. The British ambassador in Washington was asked to clarify whether this implied a speedy withdrawal of British personnel or 'something more - involving an armed clash with Persian troops'. He was informed that 'the President felt most strongly that no situation should be allowed to develop into an armed conflict between a body of British troops and the Persian forces of the existing administration' ${ }^{84}$ To further complicate matters, on 25 May the Attorney General informed his colleagues that in his opinion the UK had 'no right at all' under international law independent of a UN resolution to intervene by force either to prevent the act of nationalisation or to prevent a wrong being committed to a British national. ${ }^{85}$

In July the Foreign Office completed a study of the political implications of armed intervention at Abadan. They noted that while there might be some disquiet at the use of force without sanction by the UN, public opinion in Britain would probably support military action 'in the main'. Winston Churchill had already privately offered Attlee the support of the Conservative Party in such an eventuality. ${ }^{86}$ American opposition to the use of armed force was well known. The only circumstance in which the Americans would support the use of force was if it were in response to a revolutionary coup by the communist Tudeh party. ${ }^{87}$ The Foreign Office had considered the possibility of justifying military action on the basis that such a coup was imminent but later accepted that as such an eventuality was 'at present not demonstrable' this excuse was unlikely to appeal to world opinion in general and to American opinion in particular. ${ }^{88}$ The Foreign Office believed that within the Commonwealth the old Dominions would probably support British military action but that both India and Pakistan would be critical. Rather unkindly they concluded that 
Ceylon’s opinion, if expressed, 'would hardly matter'. ${ }^{89}$ The Foreign Office remained concerned that the Soviet Union might exploit British military action to their own advantage, possibly even invoking the 1921 Treaty as an excuse to occupy northern Iran. However, it was surmised that although the Iranian government would appeal to the UN, they would not turn to the Soviets for help as they were 'more scared of them than us'. It was anticipated that there would be much criticism from within the Arab world but that this would pass if the action were successful and might result in greater respect for the UK. In the view of the Foreign Office, 'Any other attempts to "nationalise" foreign interests would be discouraged' ${ }^{90}$

Attlee was very well aware of the difficulty of justifying intervention to protect British interests and property rather than merely to protect British lives. In June he explained to the Defence Committee that 'we must at all costs avoid getting into the position where we could be represented as a capitalist power attacking a nationalist Persia'. However, he came up with an interesting solution. He suggested that '...we should endeavour to arrange things so that our apparent position was one of supporting a legitimate Persian Government against either an invasion or a Communist civil war'. ${ }^{91}$

As a result it was decided that although there could be no question of conducting Plan Y against the existing government the plan should be adjusted to enable it to provide support for that government in the event of a Soviet attack or communist coup. ${ }^{92}$ In reality, despite the change in rationale, the plan remained largely unaffected, focusing on control of Abadan and the oil areas. ${ }^{93}$ Such action might create a stable enclave for forces loyal to the Shah, but the military planners were well aware that control of the 
oil areas might still be rather hard to represent as disinterested assistance against a communist insurgency. ${ }^{94}$

\section{Plan Buccaneer}

As the build-up of forces continued the British military position improved. As a result, on 18 June the Minister of Fuel and Power suggested that Abadan might be taken and held indefinitely, operating with oil imported from Kuwait. He also wanted consideration to be given to holding Abadan long enough to remove the 1 million tons of oil estimated to be stored there. ${ }^{95}$ The idea was examined by the Chiefs of Staff and the Cs-in-C were informed that, should Midget be met by very limited Iranian opposition, they should be prepared to reinforce and maintain the Midget forces with the object of remaining in Abadan. ${ }^{96}$ As a result by early July there were four plans for military intervention: ${ }^{97}$

1. MIDGET Protection and evacuation of British and friendly nationals. ${ }^{98}$

2. MIDGET REINFORCED To maintain Midget in order to remain in Abadan. ${ }^{99}$

3. LETHAL ${ }^{100}$ To seize Abadan Island and hold for an indefinite period. ${ }^{101}$

4. DISCIPLE To help the Iranian Government to restore order against

Communist insurrection. ${ }^{102}$

On 10 July the Ministry of Defence was informed that Midget and Midget

Reinforced had been replaced by a single plan codenamed Buccaneer, described as follows: 
Phase One. Move of forces to Abadan to cover the evacuation of friendly AIOC employees and dependents in the face of opposition by Iranian Forces.

Phase Two. To remain in Abadan to safeguard British lives and property.

Later a third phase was added, to provide for the reinforcement of phase one and/or two should they require it. Both Disciple and Lethal required a scale of forces that the British would have struggled to provide. The Cabinet were not willing to sanction the overt military preparations that would be required to prepare for operations on this scale. As a result both plans were abandoned and in late July the Cs-in-C were informed that Buccaneer was the only plan that need be 'kept in mind' ${ }^{103}$

In common with Midget, Buccaneer Phase 1 was designed to protect and evacuate British personnel and friendly nationals from Abadan. It was based upon the assumption that facilities in Iraq would be available. The military force employed would include a brigade headquarters, three infantry battalions, a squadron of tanks and an artillery field regiment less one battery. In support of the ground force were a Royal Navy cruiser, four destroyers, a frigate and the LST HMS Messina. The air transport force included a total of eighty aircraft and air support would be provided by an RAF Brigand squadron operating from Shaiba. ${ }^{104}$ A further two LSTs operated by the War Department pre-loaded with tanks and artillery were pre-positioned in the northern Gulf. These would carry the tanks and artillery for Buccaneer, embarking army personnel at Kuwait and Basra should the operation be mounted. The initial military force was to fly to Shaiba and then on to Basra by road before being transported to Abadan by HMS Messina and two destroyers. Follow on forces would come by air (infantry) and sea (heavy equipment). It was intended that AIOC 
personnel would have withdrawn to Abadan from the oilfields before Buccaneer was put into effect. Forces would concentrate in Abadan within 24 hours of the receipt of the order to move, less if pre-positioning had taken place.

Buccaneer Phase 2 was intended to reinforce and maintain forces deployed in Phase 1. The Cs-in-C also had discretion to implement Phase 2 in order to support the evacuation of AIOC personnel during Phase 1 should the need arise. The military force for Phase 2 provided an additional Guards brigade and a divisional headquarters plus engineering and administrative elements. Air support would be provided by three fighter/ground attack squadrons and one light bomber squadron. In addition to the Royal Navy ships and LSTs provided for in Phase 1, three store ships pre-loaded with 375 vehicles and 2000 tons of stores would be positioned off Bahrain ready to support intervention. ${ }^{105}$ Phase 3 was designed to build the force up to the scale of one infantry division plus an armoured regiment. It was based upon the arrival of an additional infantry brigade, two squadrons of tanks, an additional field artillery regiment plus an additional artillery battery to complete the regiment deployed under Phase 1 . The main element of this force would arrive by sea and air by D+6 although the force would not be complete within 35 days of the requisite shipping leaving the Suez Canal Zone. The Chiefs of Staff considered that Phase 3 would only be undertaken if Phase 1 and 2 went seriously wrong. ${ }^{106}$

In view of the political and military difficulties associated with intervention the Cabinet agreed on 12 July that military action in Iran, on a larger scale than that necessary for the protection of British lives, should not be contemplated unless there was a fundamental change in the situation there. ${ }^{107}$ As military preparations for 
Buccaneer continued some civilian and military leaders continued to press for more robust action to protect property as well as lives. The Chiefs of Staff advised against withdrawing from Abadan and on 18 July urged the Ministerial Committee on Persia to agree to mount Buccaneer at the end of July with the object of seizing and holding the island. ${ }^{108}$ Two days later Herbert Morrison reported to the Cabinet that preparations for Buccaneer had reached the point where it was now feasible to occupy and hold Abadan against any opposition that the Iranians unaided (i.e. by the Soviets) could mount. He resurrected the idea of holding onto Abadan and operating the refinery with imported crude. ${ }^{109}$ In a private meeting with Attlee, Morrison, Shinwell and Gaitskell in the House of Commons Churchill, accompanied by his deputy, Anthony Eden, also supported the idea of holding Abadan Island. ${ }^{110}$

The Chiefs of Staff abandoned their cautious stance of May. The First Sea Lord, Lord Fraser, informed his colleagues on the Chiefs of Staff Committee that he was 'horrified' that the idea now seemed to be that Britain should withdraw from Abadan no matter what the success of Buccaneer. He declared that withdrawal would cause a great outcry amongst the British public who were 'tired of being pushed around by Persian pip-squeaks'. He wanted the Chiefs to press Ministers to agree that if Buccaneer was put into force they should stay in Abadan and not withdraw. His colleagues agreed and the Committee recommended that the object of Buccaneer should be changed to the seizure and holding of Abadan island. ${ }^{111}$ On 20 July Slessor informed his equally hawkish subordinate at HQ Middle East Air Force that 'We are doing our utmost to persuade our masters to allow us to go in to Abadan and stay in. It is an uphill job' ${ }^{112}$ However, the Cabinet deferred any decision on military action and the restrictions of 12 July stood. 
The alert state of the forces held in readiness for Buccaneer varied through July, August and September in accordance with developments in Iran. At one stage the forces moved to three hours notice to move, although this was later reduced to 24 hours and then 72 hours as the crisis ebbed and flowed. ${ }^{113}$ At a meeting of the Ministerial Committee on 25 September the Chiefs once again argued in favour of military action and, once again, ministers decided that there could be no military action in Iran for any purpose beyond that required to protect British lives. ${ }^{114}$ That day the Iranian Government issued an ultimatum giving British AIOC personnel seven days to leave the county. In a Cabinet meeting on 27 September Morrison continued to support the military option but was overruled by his Cabinet colleagues. Attlee cited the opposition of the United States and the danger of being isolated in the UN as key political factors arguing against intervention. In addition, he noted that military action might well unite the Iranian people and government against the British and that neither the oilfields or the refinery could operate without Iranian personnel. ${ }^{115}$ On 31 September the Foreign Office announced that the few remaining entitled AIOC personnel were being withdrawn from Abadan and on 1 October Britain referred the issue to the UN. ${ }^{116}$ By 3 October all remaining AIOC personnel had been evacuated safely and with the cooperation of the Iranian security forces and on 4 October all plans for military action in Iran were stood down. ${ }^{117}$

\section{Conclusion}

The Abadan crisis demonstrated the extent to which Britain's military and political position had changed since the Second World War. Dependent on the United States for economic and military assistance, Britain could not afford to alienate its most 
powerful ally. Nor could it afford to act without due regard to opinion within the UN and the Commonwealth. There was also a lingering fear that any unilateral action on the part of Britain might be exploited by the Soviet Union. Shorn of the Indian Army and with commitments around the globe the British lacked the ready military manpower to mount a major operation in south-west Iran without denuding other areas. The military had not yet developed the concepts and equipment that would allow them to efficiently deploy limited military forces overseas. Military weakness compounded political constraints. That is not to say that the military were useless. There was an obvious need to prepare for the evacuation of British personnel should the need arise and the apparent ability of the British to intervene in Abadan may have been a constraint on the Iranian government and public. However, evacuation operations without the consent of the Iranians would have been seriously hampered by the inevitable time delay in bringing troops forward from Shaiba. Without some means of deploying troops directly into Abadan at very short notice the military were ultimately unable to guarantee the safety of British lives. Operations designed to secure property were even more problematic. The need to overtly commission and requisition shipping and to mobilise troops would telegraph British intentions leading, inevitably, to political repercussions. Britain could only provide the scale of forces required to seize and hold Abadan and the oilfields at the expense of commitments elsewhere and after the mobilisation of reserves. The crisis also demonstrated Britain's reliance on overseas bases that could be denied to them.

In any crisis where the use of military force is contemplated the ability to act quickly, before opposition forces organise and before domestic and international opinion against such action has had time to form, is likely to prove decisive. In his 
autobiography Herbert Morrison noted that 'The crux of the matter was that if military action was to be politically effective it should be quick'. ${ }^{118}$ In this sense the Chief of the Air Staff, Sir John Slessor, was right to stress the requirement for some form of 'bold and quick action' to seize Abadan island by fait accompli. Unfortunately the armed forces were in no position to provide such a response. The Parachute Brigade was not ready or available to conduct anything but the smallest airborne operation and Britain's amphibious forces were few in number, deployed at some distance from the Gulf and poorly designed for the kind of operations that were required. In May the Chiefs of Staff were forced to accept that a swift military response to the nationalisation crisis was not realistic

This was a little surprising given the disparity in national military strength between the UK and Iran. The Foreign Secretary was exasperated by this, stating that '...he was very disappointed, I view of the large expenditure on the rearmament programme to learn that so little could be done to support our foreign policy with military action' ${ }^{119}$ Unfortunately, although the rearmament programme initiated in 1950 by the Labour Government brought additional funds to the armed forces it did not bring a basic change in overall defence policy. The main priority remained the requirement to prepare for future conflict in Europe against the Soviet Union. Relatively little emphasis was placed on expeditionary forces able to project power rapidly and effectively in a wide range of circumstances. This was illustrated by the lack of a significant airborne or amphibious assault capability ready and available to respond to unforeseen crises beyond Europe. Military forces are only useful if they can be deployed at an appropriate time and place and in an appropriate fashion. Britain’s inability to do this was evident throughout this crisis. 
What Britain needed at the outbreak of the crisis in March-April 1951 was a means of bringing credible military power to bear at short notice and in a manner that was politically acceptable. This could have been provided by a fully trained and properly equipped airborne brigade, although provision of air support would have been difficult in the absence of an aircraft carrier and without use of the RAF base at Shaiba. An airborne force, lightly equipped without tanks or heavy artillery, would also have been vulnerable to Iranian counter-attack until it was reinforced by air and sea. A modern amphibious task group carrying a balanced military force and able to poise out of sight of land in the northern Gulf would have provided many useful options, either independently or in conjunction with an airborne force. It could have deployed to the crisis area without fanfare and without having to negotiate either transit rights or basing facilities. It could then have been held in a state of readiness, able to withdraw or intervene as circumstances demanded. Its embarked military force would have been able to land at Abadan at short notice, removing the dangerous pause inevitable with existing plans to fly troops through Shaiba. In many respects it was precisely such a force that spearheaded the successful British intervention in Kuwait in 1961. Unfortunately, no such capability existed in 1951, nor could it be created at short notice. From a British perspective it was unfortunate that the inability of the military to mount a rapid response to major crises overseas had to be demonstrated again, in 1956, before the armed forces developed a modern expeditionary capability.

By 20 July when Morrison announced that it was now feasible to seize and hold Abadan island it was already too late. With the United States resolutely opposed to 
military action against the existing regime, and a hostile reaction inevitable in the Arab world, it would have been extremely difficult to launch a military operation to secure Abadan without some legitimate excuse. Hence the decision on 12 July that military action would be limited to that required to protect British lives. The absence of a communist insurrection deprived Britain of the excuse to implement Plan Y/Disciple and the ability of the Iranian security forces to maintain order to Abadan removed the excuse and the need to implement Midget/Buccaneer. Unfortunately for the hawkish elements within the British political and military establishment the military only provided solutions when it was too late, by which time they were no longer solutions. With the benefit of hindsight, and in the light of the disastrous consequences of Anthony Eden's intervention in Suez, months after the act of nationalisation, against the wishes of the United States and on the flimsiest of excuses, it is hard to believe that Attlee made the wrong decision.

The analysis, opinions and conclusions expressed or implied in this article are those of the author and do not necessarily represent the views of the Joint Services Command and Staff College, the UK Ministry of Defence or any other government agency.

1 For example, see James Cable, Intervention at Abadan. Plan Buccaneer

(Basingstoke: Macmillan, 1991) chapter 11 and Wm. Roger Louis, The British Empire in the Middle East 1945-1951. Arab Nationalism, The United States and Postwar Imperialism (Oxford: Clarendon Press, 1984) p 668.

2 Cable, p.1

3 The best general work on this topic is Wm. Roger Louis’s book The British Empire in the Middle East, 1945-1951:Arab Nationalism, The United States and Post-War 
Imperialism (Oxford: Clarendon Press, 1984). However, the book is not devoted specifically to Abadan and necessarily provides incomplete coverage of the military planning process. The best work to date on the military aspects of the crisis is James Cable’s Intervention at Abadan. Plan Buccaneer (Basingstoke: Macmillan, 1991). Cable was a former British diplomat and a notable writer on international relations and naval matters. Both books are meticulously researched but are restricted by the fact that many key documents relating to the crisis were not released for public viewing until 2002. As a result neither work can provide an accurate guide to all aspects of British military planning.

${ }^{4}$ In addition to the sources noted above, see James Bill and Wm. Roger Louis (eds.): Mussadiq, Iranian Nationalism and Oil (London: I.B Taurus and Co., 1988); David Devereux, The Formulation of British Defence Policy Towards the Middle East, 1948-56 (Basingstoke: Macmillan, 1990); Mark Curtis, Ambiguities of Power. British Foreign Policy Since 1945 (London: Zed Books, 1995); Bernard Donoughue and G.W. Jones, Herbert Morrison. Portrait of a Politician (London: Weidenfeld and Nicolson, 1973).

${ }^{5}$ Cable, p.9.

${ }^{6}$ Curtis, p.88.

${ }^{7}$ John Strachey, The End of Empire, (London: Victor Gollancz, 1959) p. 162-3.

${ }^{8}$ Louis, pp. 641-51.

${ }^{9}$ Cable, p. 25.

${ }^{10}$ Sometimes spelled ‘Mossadeq' or 'Mossadegh'.

${ }^{11}$ Louis, p.657.

${ }^{12}$ In 1951 Iran was the official name for that country. However, most Britons continued to use the traditional name 'Persia' and most British records refer to 
'Persia' rather than 'Iran'. This article will use the official name throughout except for direct quotations and references to plans and reports where the original author's preference will be used.

${ }^{13}$ C.R. Attlee, As it Happened (London: William Heinemann, 1954) p.175.

${ }^{14}$ D.L.A. Wade, 'The Services in 1951-1952', in H.G. Thursfield (ed.), Brassey’s Annual. The Armed Forces Year-Book, 1952 (London: William Clowes, 1952) p. 15.

15 Anthony Farrar-Hockley, ‘The Post-War Army 1945-1963’, in David Chandler and Ian Beckett, The Oxford Illustrated History of the British Army (Oxford: Oxford University Press, 1994) p.332.

${ }^{16}$. Britain’s other wartime airborne division, $1^{\text {st }}$ Airborne Division, had been disbanded in 1945

${ }^{17}$ Peter Harclerode, Para! Fifty Years of the Parachute Regiment (London: Arms and Armour, 1992) pp. 210-13.

${ }^{18}$ COS (51) 82 mtg, 18-5-51; PRO;DEFE 4/42.

${ }^{19}$ Telegram COS (ME) 468, Ministry of Defence, London to General Headquarters., Middle East Land Forces (henceforth GHQ MELF), 18-5-51; PRO:AIR 20/8887.

${ }^{20}$ Desmond Wettern, The Decline of British Seapower (London: Jane’s, 1982), p.395

${ }^{21}$ Although numbers varied a battalion group might include roughly 700 men plus a headquarters element and some supporting arms. A brigade group would consist of three battalions, a brigade headquarters and supporting arms and administrative elements.

${ }^{22}$ Ian Speller, The Role of Amphibious Warfare in British Defence Policy, 1945-1956, (London: Palgrave, 2001) passim 
23 The Imperial Iranian Air Force was equipped with the obsolete Hawker Hurricane and Republic Thunderbolt fighters and with the Avro-Anson for general purpose duties and light bombing. H.G. Thursfield (ed.), Brassey’s Annual. The Armed Forces Year-Book, 1952 (London: William Clowes, 1952) p.366.

${ }^{24}$ During May and June No.6 Squadron, equipped with Vampire jet fighter/ground attack aircraft deployed to Shaiba in company with six rather inadequate propellerdriven Bristol Brigands from No.8 Squadron. The Brigands were later replaced by No.73 Squadron (Vampires) who deployed to Shaiba from Malta at which point No.6 Squadron re-deployed to Habbaniya. David Lee, Flight form the Middle East. A History of the Royal Air Force in the Arabian Peninsula and adjacent territories (London: HMSO, 1978) pp. 55-56

${ }^{25}$ Public Records Office, Kew (henceforth PRO): FO 371/91524. COS (51) 156, Persian Oil Industry - Nationalisation, 20-3-51; PRO:DEFE 5/29.

${ }^{26}$ In 1941 an Anglo-Soviet force occupied Iran in order to secure a supply route through that country. Soviet forces remained in Azerbaijan and Kurdistan at the end of the war and the two provinces were declared to be 'autonomous areas of Iran'. Soviet troops only withdrew in March 1946 after Iran, supported by the United States, took the issue to the UN Security Council. Devereux, p.10.

${ }^{27}$ COS (51) 52mtg, 22-3-51, PRO:AIR 20/6996. COS (51) 173, Implications of Military Action in Persia, 27-3-51; PRO:CAB 21/1982.

${ }^{28} \operatorname{COS}(51) 173$.

${ }^{29}$ GHQ MELF to Ministry of Defence, 24-3-51; in PRO:AIR 20/8032 and AIR 20/6996.

${ }^{30}$ COS (51) 53 mtg, 27-3-51, PRO:AIR 20/6996.

${ }^{31} \operatorname{COS}(51) 173$. 
${ }^{32}$ DO (51) $7^{\text {th }}$ mtg, 2-4-51; PRO:CAB 21/1982.

${ }^{33}$ COS (51) 65mtg, 13-4-51; PRO: AIR 20/8032.

${ }^{34}$ DEFE 4/42, COS (51) 74 mtg 1-5-51.

${ }^{35}$ Brief prepared by the Secretary, Chiefs of Staff Committee, Persia. Advice Given by the Chiefs of Staff to Ministers Between March and September, 1951, 31-10-51; PRO:AIR 8/1774.

${ }^{36}$ Brief for Downing Street, 9 May 1951: PRO:AIR 20/9997

${ }^{37}$ COS (51) 76 mtg, 4-5-51; PRO:DEFE 4/42. COS (51) 79 mtg, 8-5-51; PRO:DEFE $4 / 42$.

${ }^{38}$ COS (51) 81 mtg, 16-5-51; PRO:DEFE 4/42

${ }^{39}$ COS (51) 82 mtg, 18-5-51; PRO:DEFE 4/42.

${ }^{40}$ COS (51) 81 mtg, 16-5-51; PRO: AIR 20/8887.

${ }^{41}$ Telegram from Ministry of Defence to GHQ MELF, 18-5-51; PRO:AIR 20/8887.

${ }^{42}$ COS (51) 84 mtg, 21-5-51; PRO:DEFE 4/43.

${ }^{43}$ Slim had been a divisional commander during the Anglo-Soviet occupation of Persia in 1941.

${ }^{44}$ COS (51) 85 mtg, 22-5-51; PRO:DEFE 4/43.

${ }^{45}$ COS (51) 86 mtg, 23-5-51; PRO:DEFE 4/43.

${ }^{46}$ COS (51) 86 mtg, 23-5-51; PRO:DEFE 4/43.

47 COS (51) 86 mtg, 23-5-51; PRO:DEFE 4/43.

${ }^{48}$ COS (51) 87 mtg, 25-5-51; PRO:DEFE 4/43.

${ }^{49}$ CM (51) $46^{\text {th }}$ Concl. 25-6-51; PRO:CAB 128/19. Also see Foreign Office memo, Political implications of the use of force in connection with Persia, in COS (51) 305, 22-5-51; PRO:DEFE 5/31.

${ }^{50}$ COS (51) 89 mtg, 30-5-51; PRO:CAB 21/1982. 
${ }^{51}$ Telegram 463/CCL GHQ MELF to the Ministry of Defence, London, 30-6-51; PRO:AIR 20/8888.

52 PRO:FO 371/91461. Telegram 467/CCL from GHQ MELF to Ministry of Defence, London, 5-7-51; PRO:AIR 20/8888.

53 Telegram COS (ME) 494, Ministry of Defence, London to GHQ MELF, 2-7-51; PRO:AIR 20/8888.

${ }^{54}$ COS (51) 326, Possible Military Action in Persia, 31-5-51; PRO:DEFE 5/31.

${ }^{55}$ Ibid.

${ }^{56}$ Telegram 440/CCL from GHQ MELF to Ministry of Defence, London, 1-6-51; PRO:AIR 20/8888.

${ }^{57}$ Telegram 440/CCL from GHQ MELF to Ministry of Defence, London, 1-6-51; PROAIR 20/8888.

${ }^{58}$ COS 951) 89 mtg, 30-5-51, PRO:CAB 21/1982.

${ }^{59} 2$ officers and 40 men from the $1^{\text {st }}$ Battalion, The Lancashire Fusiliers were embarked on the cruiser HMS Euryalus, Cable, p.81.

${ }^{60}$ Message from HQ MEAF to the Air Ministry, 23-5-51; PRO:AIR 20/8887.

${ }^{61}$ Telegram COS (ME) 468 from Ministry of Defence, London to GHQ MELF, 18-551; PRO: AIR 20/8887. also see PRO: AIR 20/8888.

${ }^{62} \operatorname{COS}(51)$ 326, 31-5-51; PRO:DEFE 5/31.

${ }^{63}$ Cable, p.37.

${ }^{64}$ Wettern, pp. 56-7.

${ }^{65}$ Dido class cruisers such as HMS Euryalus had ten 5.25-inch guns while Fiji class ships such as Mauritius and Gambia had between nine and twelve 6-inch guns.

${ }^{66}$ Telegram from Ministry of Defence, London to GHQ MELF, 29-6-51; PRO:PREM 8/1501 - Part 2. 
${ }^{67}$ Designed during World War Two the Landing Ship, Tank (Mark 3) was originally intended to embark 15 lorries on the upper deck, 15 forty-ton tanks or 27 lorries in the tank deck and 150 soldiers in addition to the ship’s crew. These figures could be increased with some improvisation and, in the case of personnel, for short voyages. Later modifications increased the infantry lift capability of some vessels and most were eventually stiffened in order to be able to embark heavier tanks such as the Centurion. Speller, chapter 5.

${ }^{68}$ Report of Proceedings for HMS Messina for Period May 26- Sept 11, 1951; PRO:ADM 1/22414. HMS Messina was relieved by HMS Dieppe in August 1951. 69 JP (51) 111 (Final), 25-6-51 annex to COS (51) 110 mtg, 2-7-51; PRO:DEFE 4/43. ${ }^{70}$ CP (51) 172, 29-6-51; PRO:CAB 129/46.

${ }^{71} \mathrm{CP}(51) 172$.

7212 operational aircraft plus 3 spares.

73 Telegram 440/CCL GHQ MELF to Ministry of Defence, London, 1-6-51; PRO:AIR 20/8888.

${ }^{74}$ Note by DCAS dated 4-7-51; PRO:AIR 8/1776. COS (51) 524, Operation 'Buccaneer' - Air Transport Aspect, 19-9-51; PRO:AIR 8/1774. Telegram from the Air Ministry to HQ MEAF, 4-7-51; PRO:AIR 20/8888.

${ }^{75}$ DO (51) $20^{\text {th }}$ mgt, 26-7-51; PRO:CAB 131/10.

${ }^{76}$ CM (51) 46mtg, 26-6-51; CAB 21/1983.

${ }^{77}$ Telegram COS (ME) 488, Ministry of Defence, London to GHQ MELF, 25-6-51’ PRO:CAB 21/1983.

${ }^{78}$ Do (51) 18 mtg, 2-7-51; PRO:CAB 131/10. COS (51) 109 MTG, 3-7-51; PRO:AIR 20/8888. 
${ }^{79}$ COS (51) 118mtg, 20-7-51; PRO:CAB 21/3315. Telegram No. 736, from the Foreign Office to Baghdad (Embassy), 25-7-51; PRO:AIR 8/1773.

${ }^{80}$ Eric Grove, Vanguard to Trident. British Naval Policy Since World War Two (London: Bodley Head, 1987) pp. 403-410.

${ }^{81}$ COS (51) 89mtg, 30-5-51; PRO:CAB 21/1982.

${ }^{82}$ VCOS Meeting, 29-6-51; PRO:AIR 20/8888.

${ }^{83}$ Telegram from British Embassy in Washington to Foreign Office, 12-5-51; PREM 8/1501.

${ }^{84}$ Telegram from British Embassy in Washington to Foreign Office, 17-5-51; PREM 8/1501.

${ }^{85}$ Memorandum by the Attorney General, 25-5-51; PRO:PREM 8/1501.

${ }^{86}$ Record of private meeting held in the House of Commons, 27-7-1; PRO:PREM 8/1501 Part 2.

${ }^{87}$ Telegram from British Embassy in Washington to Foreign Office, 12-5-51; PREM 8/1501.

${ }^{88}$ Telegram from Foreign Office to British Embassy in Washington, 18-5-51; PRO:PREM 8/1501. Foreign Office paper, 'The Political Implications of Armed Intervention in the Persian Oil Dispute', 11-7-51; PRO:PREM 8/1501 part2.

${ }^{89}$ The refusal of Ceylon to allow the British to use facilities at their (British) base at Trincomalee for operations against Egypt during the 1956 Suez crisis would seem to indicate otherwise.

${ }^{90}$ Foreign Office paper, ‘The Political Implications of Armed Intervention in the Persian Oil Dispute', 11-7-51; PRO:PREM 8/1501 part 2.

${ }^{91}$ DO (51) 14 mtg, 4-6-51; PRO:CAB 21/1982.

${ }^{92} \operatorname{COS}(51)$ 362, 12-6-51; PRO:DEFE 5/31. 
93 JP (51) 109 (Final), 19-6-51; PRO:AIR 8/1772. PRO:AIR 20/8888.

${ }^{94}$ JP (51) 109 (Final). VCOS mtg, 22-6-51; PRO:AIR 20/8888.

${ }^{95}$ Letter from Sir Donald Fergusson to Lt-Gen Sir Kenneth McLean, 18-6-51; PRO:AIR 20/8888.

${ }^{96}$ COS (51) 100mtg, 20-6-51; PRO:DEFE 4/44. Telegram COS (ME) 490, Ministry of Defence to GHQ MELF, 29-6-51; PRO:AIR 20/8888.

${ }^{97}$ PRO:WO 216/400.

${ }^{98}$ Requiring 3 battalions.

${ }^{99}$ Required one infantry brigade group and a squadron of tanks

100 'Lethal' had briefly been called 'Dandruff' before changing to the more warlike codeword. PRO:AIR 8/1772.

${ }^{101}$ Required one infantry division (minus one infantry brigade) plus the $16^{\text {th }}$ Independent Parachute Brigade in an infantry role.

${ }^{102}$ Required an infantry division, plus an infantry brigade group and an armoured brigade group. The degree to which this rationale was a cover is illustrated by Disciple’s previous aim (28-6-51) which had been ‘An operation designed to seize and control Abadan Island and the oilfield area in South West Persia' i.e. Plan Y as originally conceived. PRO:AIR 20/8888.

103 JP (51) 132(s) Terms of Reference, 12-7-51; PRO:DEFE 6/18. JP (51) 122 (Final), 'Military Operations in South-West Persia', 31-7-51; PRO:DEFE 6/18.

${ }^{104} 40$ Hastings, 40 Valettas and 10 chartered Yorks.

${ }^{105}$ The first vessel Royal William was due to arrive from the Suez Canal Zone on 2-3 August, to be followed by the Oakmore (from Tripoli) on 14-15 August and the Pundua (Suez) on 11 August. 
${ }^{106}$ Loose Minute to 0162/821(MO4), Plans for Action in South Persian Oilfields Area, 24-7-51; PRO:WO 216/400.

${ }^{107}$ CM (51) 51 $1^{\text {st }}, 12-7-51$; PRO:CAB 21/3315.

${ }^{108}$ Persia. Advice Given by the Chiefs of Staff, 31-10-51; PRO:AIR 8/1774. p.7. ${ }^{109}$ CP (51) 212, Persia, memorandum by the Foreign Secretary, 20-7-51; PRO:CAB 21/3315

${ }^{110}$ Private Meeting in House of Commons, 27-7-51; PRO:PREM 8/1501.

${ }^{111} \operatorname{COS}(51) 117^{\text {th }}$ mtg, 17-7-51; PRO: CAB 21/3315.

${ }^{112}$ Chief of the Air Staff to C-in-C HQMEAF, 20-7-51; PRO:AIR 8/1772. For the views within HQMEAF see PRO:AIR 20/8888.

${ }^{113}$ COS (51) 120 mtg, 23-7-51; PRO:DEFE 4/45; COS (51) 128 mtg, 10-8-51; PRO:DEFE 4/46; COS (51) 137 mtg, 29-8-51; PRO:DEFE 4/46.

${ }^{114}$ Persia. Advice Given by the Chiefs of Staff, 31-10-51; PRO:AIR 8/1774 p.8.

${ }^{115}$ CM (51) 60, 27-9-51; PRO:CAB 128/20. PRO:FO 371/91591 and FO 371/915494. Louis, pp. 686-8.

${ }^{116}$ British AIOC personnel had withdrawn from the oilfields in July and August and by 31 August there were only 350 British subjects left at Abadan. Cable, p.92.

${ }^{117}$ Persia. Advice Given by the Chiefs of Staff, 31-10-51; PRO:AIR 8/1774.

${ }^{118}$ H Morrison, Herbert Morrison. An Autobiography (London: Odhams Press, 1960) p.281.

${ }^{119}$ DO (51) $14^{\text {th }} \mathrm{mtg}$, 4-6-51; PRO:CAB 21/1982. Also see JP (51) 109 (Final), Military Action in Persia,19-6-51; PRO:AIR 8/1772. 